\title{
Narkolepsijos gydymas: nuo egzorcizmo seansu ir kraujo nuleidimų iki modernios terapijos histamino receptorių atvirkštiniais agonistais
}

\author{
E. Sakalauskaitè-Juodeikienè \\ R. Masaitiené** \\ *Vilniaus universiteto ligonines \\ Santaros kliniku \\ Neurologijos centras; \\ Vilniaus universiteto Medicinos \\ fakulteto Klinikines medicinos \\ institutas, Neurologijos \\ ir neurochirurgijos klinika \\ **Vilniaus universiteto ligonines \\ Santaros kliniku \\ Neurologijos centras
}

\begin{abstract}
Santrauka. Šiame apžvalginiame straipsnyje pristatome narkolepsijos gydymą nuo senųjų laikų iki modernios terapijos šiandien. Inkubo fenomenas, šių dienų gydytojų suprantamas kaip miego paralyžius su hipnogoginėmis ar hipnopompinėmis haliucinacijomis, senovejje buvo „gydomas“, atliekant egzorcizmo seansus. XIX a. pradžioje Vilniuje inkubo liga gydyta, ligoniui pateikus gyvenimo būdo, dietos, miego higienos rekomendacijas. Didelę reikšmę turèjo antiflogistinis gydymas, taip pat skirti priešspazminiai, tonizuojantys vaistai ir chininmedžio žievè. Tik XX a. pabaigoje nustačius, kad narkolepsija - centrinės kilmės hipersomnija, pasireiškianti dèl dalinio arba visiško hipokretiną sekretuojančių neuronų netekimo pogumburyje, atsirado efektyvaus simptominio gydymo galimybių. Pirmojo pasirinkimo vaistai, iki šiol naudoti padidejjusiam mieguistumui mažinti, buvo modafinilis, armodafinilis, pitolisantas ir natrio oksibatas. Antrojo pasirinkimo - metilfenidatas. Trečiojo - amfetamino grupès psichostimuliantai. Pirmojo pasirinkimo vaistai, naudoti katapleksijos priepuoliams retinti, buvo natrio oksibatas, pitolisantas ir venlafaksinas. Antidepresantų vartojimas katapleksijos priepuoliams slopinti buvo pagrịstas ekspertų susitarimu: pirmiausia išbandyti serotonino ar serotonino ir noradrenalino reabsorbcijos inhibitoriai, nesant efekto, buvo skiriami tricikliai antidepresantai. Straipsnyje taip pat pristatomos naujos narkolepsijos gydymo gairès, paskelbtos $2020 \mathrm{~m}$. rugsejjo $5 \mathrm{~d}$. Berlyne vykusioje 17-ojoje Europos narkolepsijos konferencijoje. Pitolisantas - vienas iš naujausių vaistų, skirtų suaugusiujų I ir II tipų narkolepsijos simptominiam gydymui (patologiniam mieguistumui mažinti ir katapleksijos priepuoliams retinti), yra unikalus histamino $\mathrm{H} 3$ receptorių antagonistas / atvirkštinis agonistas, vienintelis iš rinkoje esančių pripratimo nesukeliančių CNS stimuliantų. Šiuo metu pitolisantas yra vienintelis kompensuojamasis vaistas Lietuvoje, skirtas I ir II tipų narkolepsijai gydyti. Taip pat šiame straipsnyje apžvelgiame narkolepsijos gydymo perspektyvas ateityje, paminėdamos naująsias natrio oksibato versijas, selektyvų noradrenalino reabsorbcijos inhibitorių reboksetiną, modafinilio ir astroglijos koneksinų inhibitoriaus flekainido kombinaciją, selektyvius hipokretino- 2 receptorių agonistus ir imunoterapiją.
\end{abstract}

Raktažodžiai: narkolepsija, inkubo fenomenas, hipokretinas, gydymas, histamino receptorių atvirkštiniai agonistai, pitolisantas.

\author{
Adresas: \\ Egle Sakalauskaité-Juodeikiené \\ Vilniaus universiteto ligoninès Santaros kliniku \\ Neurologijos centras \\ Santariškiu g. 2, LT-08661 Vilnius \\ El. paštas egle.sakalauskaite-juodeikiene2@santa.lt
}

\section{INKUBO FENOMENAS IR NARKOLEPSIJA}

Šių dienų mokslinėje literatūroje inkubo fenomenu vadinamas kelių sekundžių ar minučių trukmès paroksizminis su miegu susijęs fenomenas, kai pacientas jaučia spaudimą krūtinejje ir, nors suvokia esąs pabudęs, negali pajudèti dèl miego paralyžiaus. Taip pat gali pasireikšti kompleksinès vizualinės, garsinès ir kitokios rūšies haliucinacijos - ligonis mato ant krūtinès sėdinčią ar ją užgulusią į žmogų, gyvūną panašią arba fantastinę, mitologinę būtybę (1 pav.).

(C) Neurologijos seminarai, 2020. Open Access. This article is distributed under the terms of the Creative Commons Attribution 4.0 International License CC-BY 4.0 (http://creativecommons.org/licenses/by/4.0/), which permits unrestricted use, distribution, and reproduction in any medium, provided you give appropriate credit to the original author(s) and the source, provide a link to the Creative Commons license, and indicate if changes were made. 


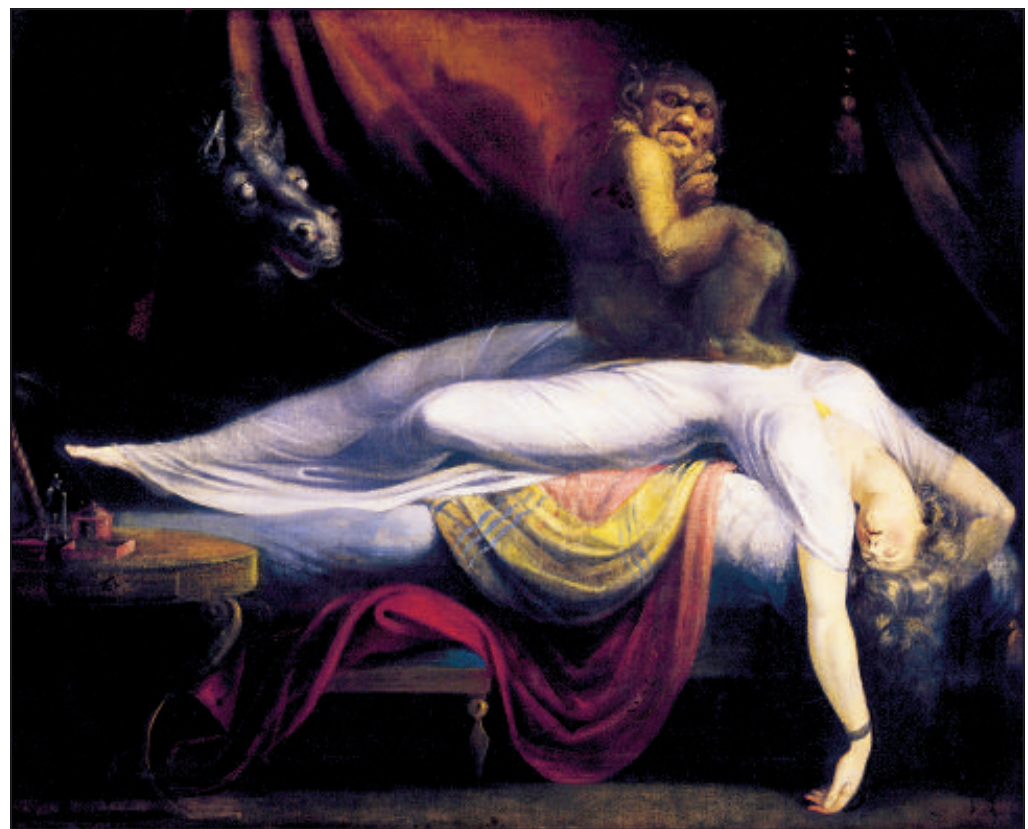

1 pav. Henrio Fuselio (Henry Fuseli; 1741-1825) drobė „Košmaras“ (1781 m.). Paveiksle, vertinant šių dienų neurologo akimis, pavaizduotas miego paralyžius su krūtinès spaudimu ir regos haliucinacijomis (inkubo fenomenas). Vieša prieiga internete.

Epizodas dažniausiai lydimas piloerekcijos, tachikardijos, pakilusio arterinio kraujospūdžio, dusulio jausmo, išpylimo šaltu prakaitu, seksualinio susijaudinimo ar net mirties baimės [1]. Izoliuotas inkubo fenomenas būdingas REM parasomnijai, tačiau, jei inkubo fenomenas pasireiškia kartu su patologiniu mieguistumu dieną, katapleksijos epizodais, šis simptomas yra narkolepsijai būdingas požymis.

Istoriškai inkubu laikytas demonas, piktoji dvasia. Senosiose civilizacijose inkubas minètas šumerų epo apie Gilgamešą epizoduose, Talmude, hebrajų Senojo Testamento Izaijo knygoje. Talmude rašoma, kad pirmoji Adomo žmona Lilita buvo demonė sukubè, pagimdžiusi ir paleidusi ị pasaulị daugybę dvasių ir demonų, naktị kankinančių miegančius [2,3]. Viduramžių tradicijoje ir vèlesnejje demonologinejje literatūroje inkubas laikytas vyriškos lyties demonu, gulinčiu virš moters jai miegant, siekiantis su ja kūniškai suartėti [2, 3]. Šio demono moteriška analogija - sukubas (lot. succumbo - gulèti (po), susmukti), kuris ateidavo naktị ir guldavosi po miegančiu vyru. Bažnyčios tèvai, tarp jų ir Aurelijus Augustinas (354-430) bei Tomas Akvinietis (1225-1274) savo teologiniuose veikaluose diskutavo inkubo klausimu, bandydami išsiaiškinti, pavyzdžiui, kaip inkubas, būdamas bekūnis demonas, galèdavo sapno metu apvaisinti vienuolyne gyvenančias vienuoles [2, 3]. Bažnytiniuose teismuose Viduramžiais ir Renesanso laikotarpiu moterys (rečiau - vyrai), miego metu turejjusios ryšių su inkubais ar sukubais, buvo kaltinamos raganavimu, patirdavo kankinimus, vykdavo egzorcizmo (tariamų „demonų“ išvarymo) seansai [3]. Kita vertus, taip pat ir asmenys, patiriantys miego paralyžius su haliucinacijomis, apkaltindavo savo kaimynus, tarnus ar pažịstamus raganavimu. Pavyzdžiui, 1692 m. Salemo (dabar - Masačusetso valstija, JAV) raganų teisme Robertas
Downer'is liudijo prieš Siuzaną Martin, kuri kartą, pasak Downer'io, pasivertusi katinu, naktį atėjo pas jị pro langą, užšoko ant jo, suèmè už gerklès ir vos neuždusino. Kitas liudytojas, Bernardas Peach'as, taip pat pasakojo, kad vieną nakti, miegodamas lovoje, išgirdo bruzdejimą už lango, tuomet ị kambarị įejusi Siuzana Martin pagriebė jį už kojų, prisitraukè ir gulèjo ant jo beveik dvi valandas, tuomet jis negalejo nei kalbèti, nei pajudèti $[4,5]$. Vertinant šiuolaikinio gydytojo akimis, veikiausiai dalis šių nelaimingujjų - kaltinamųjų ir kaltintojų - tiesiog patirdavo izoliuotas REM parasomnijas arba sirgo narkolepsija.

Olandų gydytojas ir Utrechto universiteto anatomijos ir medicinos profesorius Isbrandas van Diemerbroeck'as (1609-1674) buvo veikiausiai pirmasis, mokslinèje literatūroje $1664 \mathrm{~m}$. apibūdinęs miego paralyžių su hipnagoginèmis haliucinacijomis. Išleistame pacientų ligos istorijų rinkinyje gydytojas apraše $50 \mathrm{~m}$. amžiaus moterị, patiriančią tokius naktinius epizodus:

„...naktį, ruošdamasi užmigti, [moteris] tvirtino, kad kartais ant jos guli ir ją suspaudęs laiko velnias, kartais dusina didelis šuo ar vagis, gulèdamas ant krūtinès taip, kad ji negalinti nei kalbėti, nei kvėpuoti, o kai bando nusimesti šitą naštą, visiškai neįstengia pajudinti galūnių..." [6]

I. van Diemerbroeck'as moteriai nustatė diagnozę ir paaiškino ligos patogenezę, remdamasis keturių organizmo skysčių (humoraline) teorija. Pasak profesoriaus, ligonę kamavo inkubas, arba košmarai. Jų priežastis - spiritus animalis (dvasinio skysčio - gyvybinès jègos, susimaišiusios su pneuma), srūvančios nervais, obstrukcija ir kraujo perteklius visame organizme. Moteriai rekomenduota miegoti gryname ore, mankštintis, saikingai maitintis, vengti persivalgymo prieš miegą ir nemiegoti ant nugaros [6].

Baroko epochos mokslininkas ir gydytojas Tomas Vilizijus (1621-1675) vienas pirmụjų apibūdino patologinị mieguistumą, kurị šiandien įvardijame kaip vieną svarbiausių narkolepsijos simptomų: pasak autoriaus, jei ligoniai dieną dažnai užmiega, net ir vaikščiodami, valgydami ar dalyvaudami kitoje veikloje, tai, pasak Vilizijaus, yra ne paciento tingus iprotis, o liga [7]. Tačiau verta prisiminti, kad patologinis mieguistumas yra būdingas ne tik narkolepsijai, bet ir miego apnejjai, nuotaikos sutrikimams, skydliaukès hipofunkcijai ir kitoms ligoms.

Vilniaus imperatoriškojo universiteto profesorius Jozefas Frankas (1771-1842) vadovėlyje Praxeos medicae universae praecepta („Praktinės medicinos patarimai“), parengtame dirbant Vilniuje ir išleistame 1818 ir $1821 \mathrm{~m}$. Leipcige, nagrinėjo nervų ligas, tarp jų - ir miego sutrikimus. Miego patologijai skirtame skyriuje aprašyta liga, pavadinta incubus (lot. košmaras, slogutis), kuri, pasak profesoriaus, pasireiškia dusulio ar spaudimo jausmu krūtinè- 


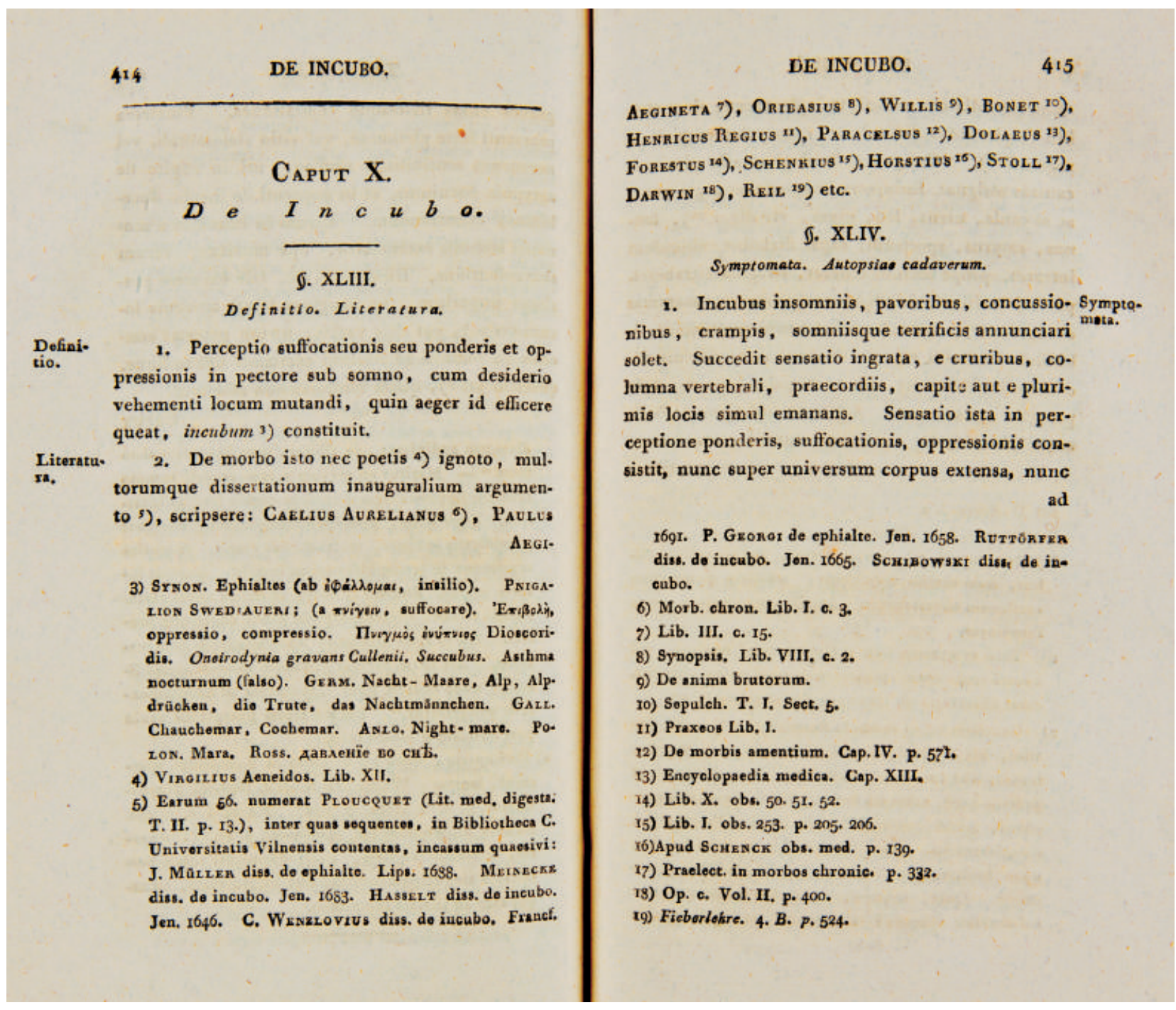

2 pav. Jozefo Franko vadovèlio Praxeos medicae universae praecepta (1818 m.) skyrius apie inkubo ligą - De incubo.

Vilniaus universiteto bibliotekos Retų spaudinių skyrius. Su leidimu.

je miego metu (2 pav.). Dūstantis ligonis sapnuodamas mato „piktą žmogų, liūtą, lokị, fauną, satyrą, velnią arba šmėklą, ateinantị prie lovos, užšokantị ant krūtinès ir ją spaudžiantị, gėdingus geidulius sukeliantị““ [8]. Ligoniui tuo metu pasireiškia prakaitavimas, širdies plakimas, ūžimas ausyse, galvos skausmas. Pasak J. Franko, dažniausia inkubo priežastis yra isterija (moterims tuo laikotarpiu priskirta liga) arba hipochondrija (isterijos atitikmuo vyrams), be to, dažnai serga „baikštūs, viršijantys trečiają dešimti jaunuoliai“" [8]. Kitos priežastys: laki ligonio vaizduotè, ịsitempimas, vidurių pūtimas, kirmèlès, sẻdimas gyvenimo būdas, „apsirijimas ir girtumas“, vèluojančios menstruacijos, per retos ejakuliacijos, troškus miegamojo oras ir tam tikra miegojimo poza (ypač gulejjimas ant nugaros). Inkubo prognoze, pasak autoriaus, yra gera - „su amžiumi praeina“" [8]. Retais atvejais inkubo liga gali pereiti i epilepsiją, maniją, melancholiją, katalepsiją (katalepsija J. Franko vadovėlyje buvo suvokiama kaip staigus judesių ir jutimų netekimas bei ligonio sustingimas, kai ligonis išlaikydavo gydytojo suteiktą galūnių ar kitų kūno dalių padèti) ar apopleksiją (apopleksija XIX a. pradžioje daugeliu atvejų buvo suvokiama kaip kraujo išsiliejimas ị smegenis). J. Frankas inkubo kankinamiems ligoniams rekomendavo keisti gyvenimo būdą, koreguoti dietą, pateikè miego higienos rekomendacijas (pvz., miegoti kietoje lovoje). Kaip ir kitų nervų ligų atveju, didžiausią reikšmę turèjo antiflogistinis gydymas: kraujo nuleidimai, klizmos, vèmimą sukeliantys vaistai. Taip pat ligoniams išrašyti vaistai nuo kirmèlių, priešspazminiai (krokas, bijūnas), tonizuojantys vaistai, chininmedžio žievè (kuri buvo dažniausiai naudota karštinėms ir įvairiems uždegimams gydyti) bei kiti vaistai [8].

\section{BIOLOGINIŲ NARKOLEPSIJOS PRIEŽASČIŲ PAIEŠKOS XIX-XX A.}

XIX a. antroje pusėje inkubo aprašymai retėjo - tiek religijos, tiek demonologinès literatūros ịtaka mažejo, siekta atrasti tikrąsias, biologines ligų priežastis. J. Caffé $1862 \mathrm{~m}$. ir Karlas Frydrichas Otas Vestfalis (1833-1890) 1877 m. publikavo klinikinius atvejus, kuriuose aprašè ligonius, 
patiriančius mieguistumo priepuolius ir raumenų tonuso bei kalbos funkcijos netekimo epizodus, tačiau šių priepuolių nelaikė atskira liga [9, 10]. Po kelerių metų, 1880-aisiais, Jean-Baptiste Gélineau (1828-1906) pirmą kartą pavartojo terminą „narkolepsija“, tačiau šią ligą vertino pirmiausia kaip naują neurozès rūšị [11].

Tik 1934 m. Luman Daniels narkolepsijai priskyrė tipišką simptomų tetradą: narkolepsiją (gr. narkē - sustingimas, lépsis - priepuolis) - staigius mieguistumo priepuolius; katapleksiją (gr. kataplēxis - išgąstis, siaubas) - staigų raumenų tonuso netekimą; hipnogogines (gr. hypnos miegas) ir hipnopompines haliucinacijas, atsirandančias prieš užmiegant arba atsibudus iš miego; bei miego paralyžių [12]. Alkaloidas efedrinas, pasižymintis simpatomimetiniu ir CNS stimuliaciniu poveikiu, buvo pirmasis cheminis vaistas, $1931 \mathrm{~m}$. rekomenduotas narkolepsijai gydyti [13]. Po kelerių metų, 1935 m., narkolepsijai gydyti pasiūlytas CNS stimuliantas amfetaminas (benzedrinas) [14].

XX a. septintajame dešimtmetyje pastebèta, kad, tiriant sergančiųjų narkolepsija miegą, REM miegas yra sutrikęs (REM miego latencija yra itin trumpa). Vèliau šis pastebėjimas turès didelę reikšmę dauginio užmigimo latencijos testo sukūrimui [15]. Histaminas pripažintas CNS neurotransmiteriu dar 1970-aisiais, o po 10 metu galvos smegenų pogumburyje buvo atrasti $\mathrm{H} 3$ receptoriai [16]. Devintajame praejjusio amžiaus dešimtmetyje pastebėtos narkolepsijos sąsajos su žmogaus leukocitų antigenų (angl. human leukocyte antigen, HLA) sistema [17], tačiau tik 2000-aisiais ịrodyta, kad ligoniams, sergantiems narkolepsija, likvore nerandama arba randama sumažejusi neuropeptido hipokretino (oreksino) koncentracija dèl šį neuropeptidą sekretuojančių neuronų žūties pogumburio posterolateralinejje srityje [18]. Beje, Konstantinas von Economo (1885-1975) jau prieš 90 metų, tirdamas letarginiu encefalitu sirgusių ir mirusių ligonių smegenis, pažeidimus rado ten pat, kur vėliau buvo nustatyti pažeidimai narkolepsija sirgusiems ligoniams. K. von Economo vienas pirmụjų nustatė, kad pakitimai rostralinejje gumburo ir vidurinių smegenų jungties dalyje ligoniams sukeldavo nemigą, o pažeidimai, esantys kaudalinejje šios jungties dalyje, patologinị mieguistumą [19].

\section{NARKOLEPSIJOS ETIOLOGIJA IR DIAGNOSTIKA ŠIANDIEN}

Šiandien narkolepsija - retas miego sutrikimas, priklausantis centrinės kilmės hipersomnijų grupei ir skirstomas ị I tipo narkolepsiją (arba narkolepsiją su katapleksija, kuri pasireiškia dèl visiško hipokretiną sekretuojančių neuronu netekimo pogumburyje) ir II tipo narkolepsiją (narkolepsiją be katapleksijos, kuri pasireiškia dèl dalinio hipokretiną sekretuojančių neuronų netekimo pogumburyje). I tipo narkolepsiją kai kurie mokslininkai vertina kaip autoimuninę ligą - jos metu galimai susidaro autoantikūnai prieš hipokretiną ir hipokretiną sekretuojančius neuronus [20]. Tikètinai autoimuninị procesą inicijuoja viršutinių kvėpa- vimo takų infekcijos (gripo virusas, ypač H1N1 padermè, infekcija Streptococcus pyogenes). Taip pat ịrodytas ryšys tarp vakcinos nuo gripo viruso A H1N1 (Pandemrix), kuria asmenys buvo skiepyti 2009-2010 m., ir padidèjusios narkolepsijos išsivystymo rizikos [21]. Hipokretinas dalyvauja palaikant normalų miego ir būdravimo ciklą dẻl sąveikos su histaminergine, noradrenergine, serotoninergine ir cholinergine sistemomis [22] bei slopina REM miegą. Nustatyta, kad narkolepsija susergama, kai netenkama apie 85-92 \% hipokretiną sekretuojančių neuronų.

Narkolepsijai išsivystyti yra svarbi genetinių ir aplinkos veiksnių sąveika. Narkolepsijos perdavimo palikuoniui rizika yra maža, siekia vos 1-2 \%, tačiau apie 90-100 \% Europos ir Šiaurès Amerikos I tipo narkolepsija sergančių gyventojų yra HLA-DR2 subtipo nešiotojai [20]. Populiacinis narkolepsijos paplitimas siekia $0,02-0,06 \%$ ir nuo lyties nepriklauso [23]. Narkolepsija dažniausiai pasireiškia dviem amžiaus tarpsniais - paauglystèje (pikas - 15 m.) arba jauno suaugusiojo amžiuje (pikas $-35 \mathrm{~m}$.).

Narkolepsiją reikètų diferencijuoti su kitomis ligomis, kurioms būdingas patologinis mieguistumas ir (ar) atonijos priepuoliai: galvos smegenų trauma, ūmiu išsėtiniu encefalomielitu, išsėtine skleroze, optiniu neuromielitu, pogumburio sarkoidoze, trečiojo skilvelio navikais, ivairios kilmès encefalitais, epilepsija, genetiniais sindromais (Coffin-Lowry, Moebius, Prader-Willi sindromais, Norrie, Niemann-Pick ligomis), miego sutrikimais (obstrukcine miego apnejja, idiopatine hipersomnija, Klein-Levino sindromu, cirkadinio ritmo sutrikimais ir kt.) [20, 24].

Narkolepsijos diagnostika yra pagrista paciento nusiskundimais, ligos anamneze, klinikiniais požymiais, instrumentiniais tyrimais. İvertinus paciento mieguistumą dieną (dažniausiai naudojama Epworth mieguistumo skale, kurios ịvertis sergantiesiems narkolepsija neretai viršija $\geq 15$ balų ir nurodo pernelyg didelị mieguistumą dieną), jei kasdienis mieguistumas tęsiasi 3 mèn. ar ilgiau, ligonis tiriamas toliau. Reikètų taip pat ịsitikinti, ar ligonis nepatiria nuolatinès miego deprivacijos, ar nedirba pamaininio darbo (nes tai gali daryti ịtaką dauginio užmigimo latencijos testo (DULT) rezultatams), ar nevartoja mieguistumą sukeliančių vaistų (benzodiazepinų, opioidų, antihistamininių, vaistų nuo epilepsijos ir kt.), ar nèra sutrikusi skydliaukès funkcija, nustatyta anemija, vit. D trūkumas, ar ligonis neserga nediagnozuotais psichikos sutrikimais (ypač depresija). Šie sutrikimai taip pat gali pasireikšti padidèjusiu mieguistumu dieną. Siekiant atmesti struktūrinius pažeidimus CNS, sukeliančius mieguistumą, kartais tenka atlikti neurovizualinius tyrimus (galvos smegenų MRT), kurie narkolepsija sergantiems ligoniams būna be pakitimų.

Atlikus polisomnografiją (PSG), sergančiajam narkolepsija dažniausiai stebimas fragmentuotas nakties miegas, trumpa REM miego latencija (REM miegas registruojamas per 15 min. nuo užmigimo), periodinių galūnių judesių sutrikimas miego metu. Rečiau gali būti nustatomas REM miego elgesio sutrikimas ar obstrukcinio tipo miego apnejja (ligoniai, sergantys narkolepsija, dažnai turi viršsvorị arba yra nutukę). Kitą dieną po PSG tyrimo atlieka- 
1 lentelè. Vaistai, naudojami narkolepsijos simptomų kontrolei (padidejjusiam mieguistumui mažinti)

\begin{tabular}{|c|c|c|c|c|}
\hline \multicolumn{2}{|l|}{ Vaistas } & Dozè, vartojimas & Veikimo mechanizmas & Nepageidaujami reiškiniai \\
\hline \multicolumn{2}{|l|}{ Pitolisantas } & $\begin{array}{l}\text { 9-36 mg, visa dozé } \\
\text { suvartojama ryte valgio } \\
\text { metu. Pradinè paros dozè yra } \\
9 \mathrm{mg} .\end{array}$ & $\begin{array}{l}\text { Histamino H3 receptorių anta- } \\
\text { gonistas / atvirkštinis agonis- } \\
\text { tas, didina histamino sintezę ir } \\
\text { jo išsiskyrimą sinapsiniame } \\
\text { plyšyje, didina smegenų hista- } \\
\text { minerginių neuronų aktyvumą } \\
\text { pogumburyje, moduliuoja } \\
\text { ìvairias neurotransmiterių sis- } \\
\text { temas, didinančias acetilcholi- } \\
\text { no, noradrenalino ir dopamino } \\
\text { išsiskyrimą į smegenis. }\end{array}$ & $\begin{array}{l}\text { Nemiga, galvos skausmas, } \\
\text { pykinimas, nerimas, galvos } \\
\text { svaigimas. Gali susilpninti } \\
\text { hormoninių kontraceptikų } \\
\text { veiksmingumą. Nera jokios } \\
\text { pripratimo, tolerancijos ir } \\
\text { piktnaudžiavimo rizikos. } \\
\text { Nerekomenduojama vartoti } \\
\text { néštumo metu. }\end{array}$ \\
\hline \multicolumn{2}{|l|}{ Modafinilis* } & $\begin{array}{l}100-200 \mathrm{mg} \times 2 \text {. } \\
\text { Dažniausiai vartojamas du } \\
\text { kartus per diena - rytais ir } \\
\text { popietemis (nevalgius). }\end{array}$ & $\begin{array}{l}\text { Veikimo mechanizmas nėa } \\
\text { iki galo aiškus: galimai dirgi- } \\
\text { na už budrumą atsakingus } \\
\text { centrus pogumburyje, didina } \\
\text { užląstelinio dopamino kon- } \\
\text { centraciją hipokretino } \\
\text { receptoriuose. }\end{array}$ & $\begin{array}{l}\text { Galvos skausmas, pykinimas, } \\
\text { burnos džiūvimas, pakilęs } \\
\text { AKS. Mažina geriamujų kon- } \\
\text { traceptikų poveiki. Maža pri- } \\
\text { pratimo, tolerancijos ir piktnau- } \\
\text { džiavimo rizika. Nerekomen- } \\
\text { duojama vartoti něštumo metu. }\end{array}$ \\
\hline \multicolumn{2}{|c|}{ Armodafinilis* } & $\begin{array}{l}\text { 100-250 mg per dieną, visą } \\
\text { dozę suvartojant ryte. }\end{array}$ & $\begin{array}{l}\text { Aktyvus modafinilio } \\
\text { R enantiomeras, mažinantis } \\
\text { mieguistumą dieną }\end{array}$ & $\begin{array}{l}\text { Galvos skausmas, nemiga, } \\
\text { pykinimas, galvos svaigi- } \\
\text { mas. Maža pripratimo, tole- } \\
\text { rancijos ir piktnaudžiavimo } \\
\text { rizika. Nerekomenduojama } \\
\text { vartoti néštumo metu. }\end{array}$ \\
\hline \multicolumn{2}{|c|}{ Natrio oksibatas* } & $\begin{array}{l}\text { Pradinė dozè }-2,25 \mathrm{~g} \times 2 \text {, di- } \\
\text { dinant iki } 3 \mathrm{~g} \times 2 \text {. Maksimali } \\
\text { paros dozė yra } 9 \text { g. Pirmoji } \\
\text { dozė išgeriama atsigulus } \\
\text { miegoti, antroji dozè - nakti, } \\
\text { praejjus } 2,5-3 \text { val. po pirmo- } \\
\text { sios dozės. Terapinis efektas } \\
\text { pasiekiamas po } 3 \text { mèn. }\end{array}$ & $\begin{array}{l}\text { Gama hidroksibutirato natrio } \\
\text { druska - neurotransmiteris ir } \\
\text { neuromoduliatorius, veikiantis } \\
\text { dopamino, serotonino, gama } \\
\text { aminosviesto rūgšties ir opioidi- } \\
\text { nes sistemas, sukeliantis CNS } \\
\text { slopinimą, miego konsolidaciją, } \\
\text { retinantis katapleksijos epizodus. }\end{array}$ & $\begin{array}{l}\text { Vartojant dideles dozes, } \\
\text { galimas sumišimas, enurezė } \\
\text { naktị, pykinimas, vangumas } \\
\text { rytais. Nerekomenduojama } \\
\text { vartoti nėštumo metu. }\end{array}$ \\
\hline \multirow[t]{3}{*}{$\begin{array}{l}\text { Amfetaminai } \\
\text { ir CNS } \\
\text { stimuliatoriai }\end{array}$} & Metilfenidatas & $\begin{array}{l}10-60 \mathrm{mg} \text { per dieną: } 10 \mathrm{mg}- \\
\text { ryte atsibudus, } 5 \mathrm{mg} \text { - prieš } \\
\text { pietus; } 5 \mathrm{mg} \text { - popiet. Jei var- } \\
\text { tojamas ilgalaikio atsipalaida- } \\
\text { vimo metilfenidatas, skiriama } \\
20 \mathrm{mg} \text { vienkartinė dozė ryte. }\end{array}$ & \multirow{3}{*}{$\begin{array}{l}\text { Slopina dopamino, noradrenali- } \\
\text { no ir serotonino atgalinị grąži- } \\
\text { nimą sinapsėse. Didina budru- } \\
\text { mą, slopina REM miegą, geri- } \\
\text { na kognityvines funkcijas, ko- } \\
\text { ordinaciją, didina jègą, ištver- } \\
\text { mę, darbingumą. Nustatyta, } \\
\text { kad metilfenidato efektyvumas } \\
\text { yra panašus į modafinilio. }\end{array}$} & \multirow{3}{*}{$\begin{array}{l}\text { Dozės, viršijančios } 60 \mathrm{mg} \\
\text { per dieną, sukelia nakties } \\
\text { miego fragmentaciją, } \\
\text { psichozę, rikošetinę } \\
\text { hipersomniją. Didelè pripra- } \\
\text { timo, tolerancijos ir piktnau- } \\
\text { džiavimo rizika. Nereko- } \\
\text { menduojama vartoti nėštumo } \\
\text { metu. }\end{array}$} \\
\hline & Metamfetaminas* & 20-25 mg per dieną & & \\
\hline & Dekstroamfetaminas* & $\begin{array}{l}5-60 \mathrm{mg} \text { per dieną: } 15 \mathrm{mg} \text { ryte, } \\
5 \mathrm{mg} \text { per pietus, } 5 \mathrm{mg} \text { popiet }\end{array}$ & & \\
\hline
\end{tabular}

*Lietuvoje neregistruotas.

Santrumpos: AKS - arterinis kraujo spaudimas, CNS - centrinė nervų sistema.

mas DULT: nustačius vidutinę užmigimo latenciją $\leq 8$ min. bei du ar daugiau REM miego epizodus užmigimo pradžioje (vieną REM miego epizodą užmigimo pradžioje DULT teste gali pakeisti PSG teste registruota $<15$ min. REM latencija), patvirtinama narkolepsijos diagnozė. Jei neatliekamas DULT, vietoj jo galima atlikti juosmens punkciją ir išmatuoti hipokretino-1 koncentraciją likvore. Sergant I tipo narkolepsija, hipokretino-1 būna $<110$ pg/ml. Tačiau II tipo narkolepsijai patvirtinti būtinas DULT, kadangi hipokretino-1 koncentracija likvore gali būti normali [23]. Taip pat verta prisiminti, kad hipokretino-1 koncentracija mažeja patyrus galvos smegenų traumą, sergant galvos smegenų augliu ar encefalitu [23]. Papildomai narkolepsijos diagnostikai gali būti atliekami genetiniai tyrimai - HLA subtipų alelių nustatymas kraujyje.

\section{MODERNUS NARKOLEPSIJOS GYDYMAS}

Pacientų, sergančių narkolepsija, gydymo tikslas - pagerinti simptomų kontrolę ir ligonio gyvenimo kokybę. Išgydyti narkolepsijos šiuo metu vis dar neįmanoma.

Gyvenimo būdo korekcija, miego higienos rekomendacijos. Pacientai, sergantys narkolepsija, neturètų dirbti pamaininio darbo, darbo transporto sektoriuje (nerekomenduojama dirbti profesionaliais vairuotojais) ir bet kokio monotoniško darbo (pvz., su automatizuotais mechanizmais), kuri atliekant yra tikimybė užsnūsti. Darbdavys turẻtų sudaryti sąlygas darbuotojui, sergančiam narkolepsija, darbo metu kas 4 val. nusnūsti bent po 20 min. Rekomenduojama laikytis miego režimo, miego higienos rekomendacijų, vengti dažnų laiko zonos kirtimų, koreguoti dietą, nepersivalgyti [23]. 
2 lentelè. Vaistai, naudojami narkolepsijos simptomų kontrolei (katapleksijos priepuoliams retinti, taip pat naudingi miego paralyžių ir haliucinacijų kontrolei)

\begin{tabular}{|c|c|c|c|c|}
\hline \multicolumn{2}{|l|}{ Vaistas } & Dozė & Veikimo mechanizmas & Nepageidaujami reiškiniai \\
\hline \multicolumn{2}{|l|}{ Pitolisantas } & $\begin{array}{l}\text { 9-36 mg, visa doze } \\
\text { suvartojama ryte valgio } \\
\text { metu. Pradinè paros dozè } \\
\text { yra } 9 \mathrm{mg} .\end{array}$ & $\begin{array}{l}\text { Histamino H3 receptorių antago- } \\
\text { nistas / atvirkštinis agonistas, di- } \\
\text { dina histamino sintezę ir jo išsis- } \\
\text { kyrimą sinapsiniame plyšyje, di- } \\
\text { dina smegenų histaminerginių } \\
\text { neuronų aktyvumą pogumburyje, } \\
\text { moduliuoja ịvairias neurotransmi- } \\
\text { terių sistemas, didinančias acetil- } \\
\text { cholino, noradrenalino ir dopami- } \\
\text { no išsiskyrimą i̇ smegenis. }\end{array}$ & $\begin{array}{l}\text { Nemiga, galvos skausmas, } \\
\text { pykinimas, nerimas, galvos } \\
\text { svaigimas. Gali susilpninti } \\
\text { hormoninių kontraceptikų } \\
\text { veiksmingumą. Nėra jokios } \\
\text { pripratimo, tolerancijos ir } \\
\text { piktnaudžiavimo rizikos. } \\
\text { Nerekomenduojama vartoti } \\
\text { néštumo metu. }\end{array}$ \\
\hline \multicolumn{2}{|c|}{ Natrio oksibatas* } & $\begin{array}{l}\text { Pradinė dozė }-2,25 \mathrm{~g} \times 2 \text {, } \\
\text { didinant iki } 3 \mathrm{~g} \times 2 \text {. } \\
\text { Maksimali paros dozė yra } \\
9 \mathrm{~g} . \text { Pirmoji dozė išgeriama } \\
\text { atsigulus miegoti, antroji } \\
\text { dozè - nakti, praėjus } \\
2,5-3 \text { val. po pirmosios } \\
\text { dozės. Terapinis efektas } \\
\text { pasiekiamas po } 3 \text { mėn. }\end{array}$ & $\begin{array}{l}\text { Gama hidroksibutirato natrio } \\
\text { druska - neurotransmiteris ir neu- } \\
\text { romoduliatorius, veikiantis dopa- } \\
\text { mino, serotonino, gama amino- } \\
\text { sviesto rūgšties ir opioidines siste- } \\
\text { mas, sukeliantis CNS slopinimą, } \\
\text { miego konsolidaciją, retinantis } \\
\text { katapleksijos epizodus (dėl sąvei- } \\
\text { kos su dopaminergine sistema ir } \\
\text { dėl REM miego konsolidacijos). }\end{array}$ & $\begin{array}{l}\text { Vartojant dideles dozes, } \\
\text { galimas sumišimas, enurezė } \\
\text { nakti, pykinimas, vangumas } \\
\text { rytais. Nerekomenduojama } \\
\text { vartoti nėštumo metu. }\end{array}$ \\
\hline \multirow{4}{*}{\begin{tabular}{||l|} 
Selektyvūs \\
serotonino, \\
serotonino- \\
noradrenalino \\
reabsorbcijos \\
inhibitoriai
\end{tabular}} & \begin{tabular}{|l|} 
Venlafaksinas \\
(ilgalaikio \\
atsipalaidavimo) \\
\end{tabular} & $\begin{array}{l}75-300 \mathrm{mg} \text { per dieną, } \\
\text { pradine dozé - } 37,5 \mathrm{mg} \text { ryte }\end{array}$ & \multirow{4}{*}{$\begin{array}{l}\text { Slopina serotonino, } \\
\text { noradrenalino atgalinị grąžinimą } \\
\text { sinapsėse. Retina katapleksijos } \\
\text { epizodus, miego paralyžius, } \\
\text { slopina hipnogogines ir } \\
\text { hipnopompines haliucinacijas. }\end{array}$} & \multirow{4}{*}{$\begin{array}{l}\text { Mažiau efektyvūs nei tricik- } \\
\text { liai antidepresantai, tačiau } \\
\text { saugesni. Nepageidaujami } \\
\text { reiškiniai: nemiga, pykini- } \\
\text { mas, erektilinė disfunkcija. } \\
\text { Gali išprovokuoti ar pasun- } \\
\text { kinti neramių kojų sindromą. } \\
\text { Esant būtinybei, něštumo } \\
\text { metu vartoti galima, tačiau } \\
\text { prieš III něštumo trimestrą } \\
\text { rekomenduojama vaistą } \\
\text { palaipsniui nutraukti. }\end{array}$} \\
\hline & Fluoksetinas & $\begin{array}{l}20-60 \mathrm{mg} \text { per dieną, } \\
\text { pradedant nuo } 10-20 \mathrm{mg} \\
\text { ryte ir palaipsniui didinant. }\end{array}$ & & \\
\hline & Duloksetinas & $\begin{array}{l}60 \mathrm{mg} \text { per dieną, skiriamas } \\
\text { ryte. }\end{array}$ & & \\
\hline & Viloksazinas* & 50-200 mg per dieną & & \\
\hline \multirow[b]{4}{*}{$\begin{array}{l}\text { Tricikliai } \\
\text { antidepresantai }\end{array}$} & Klomipraminas & \multirow[t]{3}{*}{ 25-200 mg per dieną } & \multirow{4}{*}{$\begin{array}{l}\text { Slopina dopamino, noradrenalino } \\
\text { ir serotonino atgalinị grąžinimą } \\
\text { sinapsėse, taip pat slopina } \\
\text { cholinerginę, histaminerginę ir } \\
\text { adrenerginę sistemas. Istoriškai - } \\
\text { vieni pirmųjų vaistų, skirtų } \\
\text { katapleksijos priepuoliams } \\
\text { slopinti. }\end{array}$} & \multirow{4}{*}{$\begin{array}{l}\text { Naudojami tuomet, jei SSRI } \\
\text { ar SNRI grupės antidepre- } \\
\text { santai yra neefektyvūs. Anti- } \\
\text { cholinerginis poveikis: } \\
\text { burnos džiūvimas, obstipaci- } \\
\text { jos, padidejęs prakaitavimas, } \\
\text { tachikardija, šlapinimosi } \\
\text { sutrikimai, erektilinè dis- } \\
\text { funkcija. Nerekomenduoja- } \\
\text { ma vartoti něštumo metu. }\end{array}$} \\
\hline & Imipraminas* & & & \\
\hline & Desipraminas* & & & \\
\hline & Protriptilinas* & 2,5-20 mg per parą & & \\
\hline
\end{tabular}

*Lietuvoje neregistruotas.

Santrumpos: CNS - centrinė nervų sistema, SSRI - selektyvūs serotonino reabsorbcijos inhibitoriai, SNRI - serotonino ir noradrenalino reabsorbcijos inhibitoriai.

Farmakoterapija. Vaistai, naudojami narkolepsijai gydyti (patologiniam mieguistumui mažinti, nakties miegui stabilizuoti ir katapleksijos priepuoliams slopinti), pateikti 1 ir 2 lentelèse. Pirmojo pasirinkimo vaistai, iki šiol naudoti padidejjusiam mieguistumui mažinti, buvo šie: modafinilis, armodafinilis, pitolisantas ir natrio oksibatas. Antrojo pasirinkimo vaistai - metilfenidatas. Trečiojo amfetamino grupés psichostimuliantai [25]. Pirmojo pasirinkimo vaistai, iki šiol naudoti katapleksijos priepuoliams retinti, buvo natrio oksibatas, pitolisantas ir venlafaksinas. Antidepresantų efektyvumas, slopinant katapleksijos priepuolius, nèra įrodytas klinikiniais tyrimais, jų vartojimas buvo pagrịstas tik ekspertų susitarimu: pirmiausia išbandyti SSRI (selektyvūs serotonino reabsorbcijos inhibitoriai) ar SNRI (serotonino ir noradrenalino reabsorbcijos inhibitoriai) grupės antidepresantai, nesant efekto, buvo galima skirti triciklius antidepresantus (kiti nei venlafaksinas SNRI ar SSRI buvo antrojo pasirinkimo vaistai, tricikliai antidepresantai - trečiojo pasirinkimo vaistai) $[25,26]$.

Nors Vakarų Europos šalyse vaistu pasirinkimas yra pakankamas, ilgą laiką Lietuvoje iš mieguistumą slopinančiu vaistų buvo registruotas tik CNS stimuliantas metilfenidatas (antrojo pasirinkimo vaistas) [27], iš retinančiu katapleksijos priepuolius - antidepresantai venlafaksinas, 
duloksetinas, fluoksetinas ir klomipraminas (taip pat antrojo ir trečiojo pasirinkimo vaistai) [28-31]. Pastebima, kad narkolepsijos gydymas pasirinktu vaistu ar jų kombinacija neretai būna nepakankamai efektyvus (mažinamas mieguistumas dieną, retinami katapleksijos priepuoliai, tačiau vaisto dozès didinimą riboja paciento pripratimo ir galimo piktnaudžiavimo rizika, išsivystę nepageidaujami reiškiniai), ligoni vargina nepatogi dozavimo schema (pvz., vartojant natrio oksibatą, pirmoji vaisto dozė išgeriama atsigulus miegoti, antroji dozè - naktį, praejus 2,5-3 val. po pirmosios dozès; metilfenidato vartojimas tris kartus per dieną - ryte, prieš pietus ir vèlyvą popietę ligoniui taip pat gali būti nepatogus, pacientai dažnai pamiršta ir praleidžia dozes) [32]. Tad pripratimo nesukeliančio, saugaus ir patogaus vartoti vaisto paieška tapo itin svarbi pacientų, sergančių narkolepsija, gydymo efektyvumui gerinti.

Imunoterapija. Manoma, kad narkolepsija yra autoimuninè liga, todèl ligos pradžioje bandyta ligoniams skirti plazmaferezes, kortikosteroidus, intravenines imunoglobulino infuzijas, gydymą rituksimabu ar alemtuzumabu. Deja, šio gydymo rezultatai buvo prieštaringi - veikiausiai dẻl labai mažos pacientų imties, kitų priežasčių (nuo narkolepsijos simptomų pasireiškimo iki teisingos diagnozès nustatymo gali praeiti net keleri metai, tuomet hipokretiną sekretuojančių neuronų netekimas pogumburyje yra negrịžtamas) [23, 25].

Psichoterapija. Narkolepsija sergantiems asmenims neretai nustatomi psichikos sutrikimai - nuotaikos, nerimo, valgymo sutrikimai, dėmesio trūkumo ir hiperaktyvumo sindromas [25]. Ligonių, sergančių narkolepsija, psichoterapinis gydymas turi svarbią reikšmę kontroliuojant šias gretutines ligas, taip pat mažinant nerimą, susijusị su patiriamais miego paralyžiais ir hipnogoginèmis ar hipnopompinėmis haliucinacijomis.

Gretutinių ligų gydymas. Dalis ligonių, sergančių narkolepsija, yra nutukę, serga obstrukcine miego apneja. Simptominiam miego apnejos gydymui gali prireikti taikyti nuolatinio teigiamo slègio ventiliaciją (angl. continuous positive airway pressure, CPAP) miego metu. Nuotaikos sutrikimams gydyti yra svarbūs antidepresantai ir psichoterapija. REM miego parasomnijos gydymui narkolepsija sergantiems ligoniams pastebètas teigiamas klonazepamo ir melatonino efektas. Verta prisiminti, kad katapleksijos priepuoliams slopinti arba depresijai gydyti skiriami antidepresantai gali pasunkinti narkolepsija sergančių ligonių neramių kojų sindromą ir periodinių galūnių judesių sutrikimą miego metu [26].

Naujos narkolepsijos gydymo gairès Europoje. C. Bassetti ir U. Kallweit 2020 m. rugsejjo 5 d. Berlyne vykusioje 17-ojoje Europos narkolepsijos konferencijoje pristatė dar nepublikuotas, tačiau tiek Europos neurologijos akademijos (European Academy of Neurology, EAN), Europos miego tyrimų draugijos (European Sleep Research Society, ESRS), tiek Europos narkolepsijos tinklo (European Narcolepsy Network, EU-NN) patvirtintas naujas narkolepsijos gydymo gaires Europoje, kurių santrauka pateikta 3 lentelèje.
3 lentelè. Naujos suaugusiụjų narkolepsijos gydymo gairès Europoje, paskelbtos 2020 m. rugsèjo 5 d. Berlyne vykusioje 17-ojoje Europos narkolepsijos konferencijoje. Parengtos remiantis Bassetti C, Kallweit U. New European Management Guidelines [oral presentation]. 17th European Narcolepsy Masterclass; 5 Sep 2020; Berlin [45].

\section{Imunoterapija. Nėra pakankamai įrodymų, kad} intraveniniai imunoglobulinai, plazmaferezès, steroidai ar monokloniniai antikūnai, skirti narkolepsija sergantiems ligoniams, pasižymètų ligą modifikuojančiu poveikiu ar sukeltų ligos remisiją.

Nefarmakologinis simptominis gydymas. Nèra pakankamai ịrodymų, kad fizinis aktyvumas, specialios dietos ar kognityvinė psichoterapija būtu veiksmingi narkolepsija sergančių ligonių simptomų korekcijos būdai. Tačiau suplanuoti nusnūdimai dieną rekomenduojami kaip reikšmingas nefarmakologinis simptominis gydymas (stipri rekomendacija).

Gretutiniu ligu gydymas. Nėra pakankamai ịrodymų, kad tokių gretutinių ligų, kaip psichikos sutrikimų, neramių kojų sindromo, REM miego elgesio sutrikimo, gydymas narkolepsija sergantiems ligoniams pagerintų jų būklę ar gyvenimo kokybę. Tačiau miego apnèjos gydymas rekomenduojamas narkolepsija sergantiems ligoniams (silpna rekomendacija).

\section{PIRMOJO PASIRINKIMO medikamentinis gydymas.}

1. Vyraujant patologiniam mieguistumui diena (budruma didinantys vaistai):

- modafinilio / pitolisanto / solriamfetolio* monoterapija.

2. Vyraujant patologiniam mieguistumui diena ir katapleksijos priepuoliams:

- natrio oksibato** / pitolisanto monoterapija

- venlafaksinas / klomipraminas + pirmojo pasirinkimo budrumą didinantys vaistai

- natrio oksibatas** + pirmojo pasirinkimo budrumą didinantys vaistai.

3. Vyraujant patologiniam mieguistumui diena, katapleksijos priepuoliams ir sutrikusiam miegui nakties metu: - natrio oksibato** monoterapija

- natrio oksibatas ${ }^{* *}$, venlafaksinas / klomipraminas + pirmojo pasirinkimo budrumą didinantys vaistai

- bet kuris budrumą didinantis vaistas, venlafaksinas / klomipraminas + Z-grupés hipnotikai ${ }^{* * *}$ (zolpidemas, zopiklonas).

ANTROJO PASIRINKIMO medikamentinis gydymas, jei po 4-6 sav. skirto gydymo pirmojo pasirinkimo vaistais adekvačiomis dozèmis efekto nèra arba jis nepakankamas.

1. Vyraujant patologiniam mieguistumui diena (gydymas vaistų deriniais arba monoterapija):

- pitolisantas + modafinilis / solriamfetolis*

- natrio oksibatas ${ }^{* *}+$ bet kuris budrumą didinantis vaistas

- natrio oksibato**/ metilfenidato / amfetamino grupès stimuliatoriaus monoterapija.

2. Vyraujant patologiniam mieguistumui diena ir katapleksijos priepuoliams:

- keisti natrio oksibatą ** venlafaksinu / klomipraminu ir atvirkščiai

- natrio oksibatas**, venlafaksinas / klomipraminas + pirmojo pasirinkimo budrumą didinantys vaistai

- keisti venlafaksiną / klomipraminą kitu antidepresantu.

*Duomenys iš tyrimų, tačiau per mažai klinikinès patirties.

**Prieš pradedant gydyti natrio oksibatu, reikia atmesti miego apnèją.

***Rekomenduojamas trumpalaikis gydymas, išimties tvarka. 


\section{HISTAMINO RECEPTORIŲ ATVIRKŠTINIŲ AGONISTŲ REIKŠMÉ}

Pitolisantas - histamino H3 receptorių antagonistas / atvirkštinis agonistas, vienas naujausių ir saugiausių, pripratimo nesukeliančių CNS stimuliatorių, skirtas suaugusiujų I ir II tipų narkolepsijos (TLK-10 AM kodas G47.4) simptominiam gydymui, patvirtintas Europos Sajungoje (ES) ir Jungtinèse Amerikos Valstijose (JAV), registruotas [33] ir nuo $2020 \mathrm{~m}$. ịtrauktas ị kompensuojamųjų vaistų A sąrašą Lietuvoje [34]. Pitolisantas, blokuodamas histamino H3 autoreceptorius neuronų presinapseje, padidina histamino sintezę ir jo išsiskyrimą sinapsiniame plyšyje, didina smegenų histaminerginių neuronų aktyvumą pogumburio $\mathrm{nu}$ cleus tuberomammillaris (3 pav.). Išsiskyręs histaminas aktyvuoja postsinapsinius histamino receptorius ir moduliuoja įvairias neurotransmiterių sistemas, didinančias acetilcholino, noradrenalino ir dopamino išsiskyrimą į smegenis.

Tiriant ligonius, sergančius narkolepsija su katapleksija (arba be jos), nustatyta, kad pitolisantas padidina budrumo ir aktyvumo lygị ir trukmę dieną. Pagrindiniame, dvigubai aklame, atsitiktinių imčių, placebu ir modafiniliu (iki $400 \mathrm{mg}$ per parą) kontroliuojamame tyrime (Harmony 1) [35] dalyvavo 94 pacientai (31 pacientas buvo gydomas pitolisantu, 30 - placebu ir 33 - modafiniliu). Pradinė pitolisanto dozė buvo $9 \mathrm{mg}$ per parą, kuri, atsižvelgiant i veiksmingumą ir toleravimą, buvo padidinta iki $18 \mathrm{mg}$ arba $36 \mathrm{mg}$ per parą 1 savaitę. Modafinilio grupès pacientams šio vaisto skirta iki $400 \mathrm{mg}$ per dieną. Siekiant įvertinti pitolisanto veiksmingumą, gydant patologinị mieguistu- mą dieną, kaip pagrindinis veiksmingumo kriterijus buvo naudojamas Epworth mieguistumo skalès ịvertis. Pitolisantą vartojusios grupès rezultatai buvo reikšmingai didesni, lyginant su placebo grupès (vidutinis skirtumas buvo $-3,0 ; 95 \%$ CI [nuo -5,6 iki -0,4]; p < 0,05), tačiau reikšmingai nesiskyrè nuo modafinili vartojusios grupès rezultatų (vidutinis skirtumas - 0,12; 95 \% CI [nuo -2,5 iki 2,7]). Pacientams katapleksijos priepuolių dažnis reikšmingai sumažejo ( $\mathrm{p}=0,034)$ pitolisanto grupeje $(-62 \%)$, lyginant su placebo grupe $(-8 \%)$ [35]. Pitolisanto toleravimas buvo kiek geresnis nei modafinilio. Pitolisanto efektyvumas taip pat buvo ịrodytas Harmony Ibis, Harmony CTP [36] ir Harmony III [37] klinikiniuose tyrimuose.

Gydymą pitolisantu turi paskirti gydytojas, turintis miego sutrikimų gydymo patirties, patvirtinęs narkolepsijos diagnozę. Atsižvelgiant ị kiekvieno paciento vaisto toleravimą, rekomenduojama vartoti mažiausią pitolisanto dozę pagal titravimo schemą. Pitolisanto dozè negali viršyti $36 \mathrm{mg}$ per parą. Pitolisantas vartojamas vieną kartą per dieną - ryte, valgio metu. Vaisto didinimo schema pavaizduota 4 lenteleje. Pacientams, kurių inkstų funkcija yra sutrikusi, turi būti skiriama ne didesnė nei $18 \mathrm{mg}$ paros dozè. Pacientams, kuriems yra vidutinio sunkumo (ChildPugh B) kepenų funkcijos sutrikimas, dvi savaites nuo gydymo pradžios paros dozė gali būti padidinta, neviršijant didžiausios $18 \mathrm{mg}$ dozès. Pitolisanto negalima skirti pacientams, kuriems nustatytas sunkus (Child-Pugh C) kepenų funkcijos sutrikimas [38].

Pitolisanto vartojimo absoliučios kontraindikacijos: padidèjęs jautrumas veikliajai arba pagalbinei medžiagai,

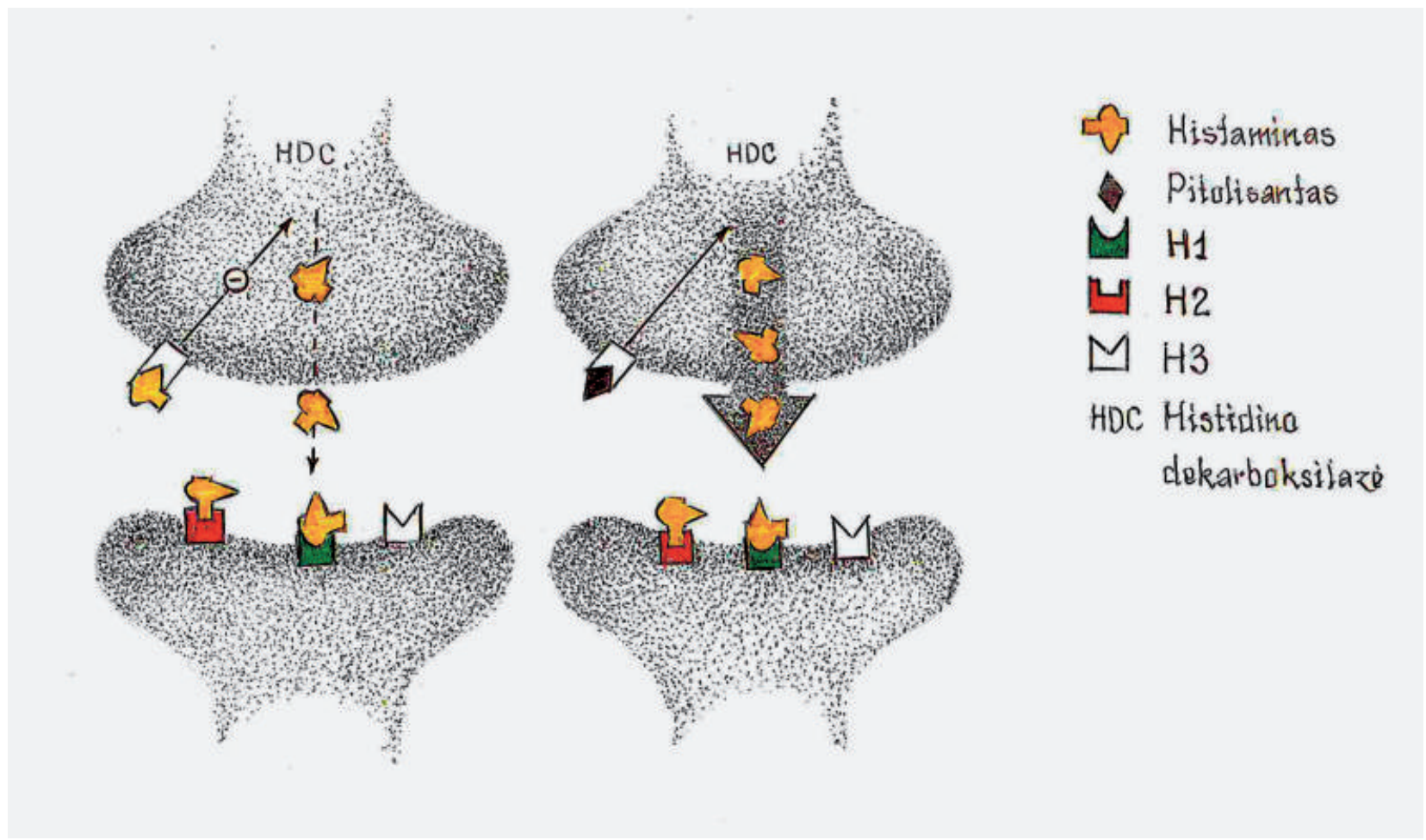

3 pav. Schema, vaizduojanti pitolisanto veikimo pradžią neuronų sinapsiniame plyšyje.

Loretos Juodeikienès piešinys, parengtas remiantis Lin JS. Brain structures and mechanisms involved in the control of cortical activation and wakefulness, with emphasis on the posterior hypothalamus and histaminergic neurons. Sleep Medicine Reviews 2000; 4(5): 471-503 [46]. 
4 lentelè. Pitolisanto skyrimas, didinimas ir efektyvumo stebėsena

\begin{tabular}{|c|c|}
\hline Etapas & Paaiškinimai \\
\hline $\begin{array}{l}\text { Narkolepsijos diagnozės nustatymas, } \\
\text { indikacijų ir kontraindikacijų } \\
\text { ịvertinimas }\end{array}$ & $\begin{array}{l}\text { Remdamasis nusiskundimais, klinika, patologinio mieguistumo klausimynais, PSG, } \\
\text { DULT tyrimų duomenimis, narkolepsijos diagnozę nustato gydytojas neurologas, miego } \\
\text { medicinos specialistas. Būtina atmesti sunkų kepenų nepakankamumą. İsitikinama, kad } \\
\text { narkolepsija serganti paciente nėra nėščia, nežindo kūdikio. Jei pacientè vartoja hormo- } \\
\text { ninius kontraceptikus, turi būti pasirenkamas kitas veiksmingas kontracepcijos metodas. }\end{array}$ \\
\hline Pitolisanto paskyrimas: 1 savaitė & Pradinė paros dozè - $9 \mathrm{mg}$ (dvi 4,5 mg tabletès), visa dozė suvartojama ryte. \\
\hline Gydymo pitolisantu tęsimas: 2 savaitė & $\begin{array}{l}\text { Dozè gali būti padidinta iki } 18 \mathrm{mg} \text { (vienos } 18 \mathrm{mg} \text { tabletės) per parą arba sumažinta iki } \\
4,5 \mathrm{mg} \text { (vienos } 4,5 \mathrm{mg} \text { tabletės) per parą, visa dozè suvartojama ryte. }\end{array}$ \\
\hline Gydymo pitolisantu tęsimas: 3 savaitė & $\begin{array}{l}\text { Dozė gali būti padidinta iki } 36 \mathrm{mg} \text { (dviejų } 18 \mathrm{mg} \text { tablečių) per parą, visą dozę } \\
\text { suvartojant ryte. }\end{array}$ \\
\hline $\begin{array}{l}\text { Gydymo pitolisantu tęsimas ir } \\
\text { tolesnio veiksmingumo vertinimas }\end{array}$ & $\begin{array}{l}\text { Dozė gali būti bet kada sumažinta (iki } 4,5 \mathrm{mg} \text { per parą) arba padidinta (iki } 36 \mathrm{mg} \text { per } \\
\text { parą), atsižvelgiant ị paciento savijautą, gydymo efektyvumą, galimus nepageidaujamus } \\
\text { reiškinius. Bendra paros dozè turi būti vartojama kaip vienkartinė dozė ryte per } \\
\text { pusryčius (valgio metu). Gydytojas neurologas (miego medicinos specialistas) } \\
\text { reguliariai vertina tolesnį gydymo pitolisantu veiksmingumą. }\end{array}$ \\
\hline
\end{tabular}

Santrumpos: PSG - polisomnografija, DULT - dauginis užmigimo latencijos testas.

sunkus kepenų funkcijos sutrikimas, žindymas. Vaisto taip pat nerekomenduojama vartoti nėštumo metu. Pitolisanto reikia atsargiai skirti pacientams, kuriems yra buvę psichikos sutrikimų (didelis nerimas ar sunki depresija su savižudybės rizika). Šio vaisto reikia atsargiai skirti pacientams, kuriems pasireiškẻ skrandžio rūgštingumo sutrikimų arba kurie kartu vartoja skrandžio gleivinę dirginančių preparatų, pavyzdžiui, kortikosteroidų ar nesteroidinių vaistų nuo uždegimo (NVNU). Pitolisanto reikia atsargiai skirti ligoniams, kuriems nustatyta sunki nutukimo arba anoreksijos forma. Klinikinių tyrimų metu, naudojant terapines pitolisanto dozes, nebuvo nustatyta jokių poveikio širdžiai požymių. Tačiau pacientai, kurie serga širdies ligomis ir yra gydomi QT intervalą ilginančiais preparatais arba kuriems nustatyta padidejusi repoliarizacijos sutrikimų rizika, turi būti atidžiai stebimi. Sunkia epilepsija sergantiems pacien- tams pitolisantą taip pat reikètų skirti atsargiai [38]. Pitolisantas gali susilpninti hormoninių kontraceptikų veiksmingumą, todèl, jei pacientė vartoja hormoninių kontraceptikų, turi būti taikomas kitas veiksmingas kontracepcijos metodas (pvz., intrauterinè spiralè).

Pitolisantas yra lengvai ir greitai absorbuojamas, didžiausia vaisto koncentracija kraujo plazmoje pasiekiama praejjus maždaug 3 valandoms po suvartojimo. Pitolisantui būdingas didelis serumo baltymų prisijungimo pajègumas (>90\%). Šio vaisto pusinès eliminacijos iš kraujo plazmos periodas yra 10-12 valandų. Eliminacija daugiausia vyksta per šlapimą (pašalinama maždaug $63 \%$ vaisto); $25 \%$ dozès išsiskiria su iškvepiamu oru ir nedidelè dalis $(<3 \%)-$ su išmatomis [38].

Pitolisanto sąveika su kitais vaistais apibendrinta 5 lentelèje. Šio vaisto ir CYP3A4 substratų derinys bei siauros

5 lentelè. Pitolisanto sąveika su kitais vaistiniais preparatais

\begin{tabular}{||l|l||}
\hline Vaistų grupe & Pitolisanto sąveika su vaistiniu preparatu \\
\hline Antidepresantai & $\begin{array}{l}\text { Tricikliai arba tetracikliai antidepresantai (pvz., imipraminas, klomipraminas, mirtazapinas) gali silpninti } \\
\text { pitolisanto veiksmingumą, nes jie blokuoja histamino H1 receptorius ir panaikina endogeninio histamino, } \\
\text { kuris, gydant pitolisantu, išskiriamas į smegenis, poveiki. }\end{array}$ \\
\hline $\begin{array}{l}\text { Antihistamininiai } \\
\text { vaistai }\end{array}$ & $\begin{array}{l}\text { Antihistamininiai vaistai (H1 receptorių blokatoriai), prasiskverbiantys pro hematoencefalinį barjerą (pvz., } \\
\text { feniramino maleatas, chlorfeniraminas, difenhidraminas, prometazinas, mepiraminas), gali silpninti } \\
\text { pitolisanto veiksmingumą. }\end{array}$ \\
\hline $\begin{array}{l}\text { CYP fermentų } \\
\text { induktoriai }\end{array}$ & $\begin{array}{l}\text { Reikia atsargiai vartoti pitolisantą kartu su stipriais CYP3A4 induktoriais (pvz., rifampicinu, fenobarbitaliu, } \\
\text { karbamazepinu, fenitoinu), nes sumažeja pitolisanto Cmax ir AUC santykis. Pitolisantą taip pat reikia atsar- } \\
\text { giai vartoti kartu su jonažolès (Hypericum perforatum) preparatais dèl jos stipraus CYP3A4 indukuojančio } \\
\text { poveikio. Nustatyta, kad pitolisanto derinys su probenecidu sumažina pitolisanto AUC apie 34 \%. }\end{array}$ \\
\hline $\begin{array}{l}\text { CYP fermentu } \\
\text { inhibitoriai }\end{array}$ & $\begin{array}{l}\text { Pitolisantą reikia atsargiai vartoti kartu su CYP2D6 inhibitoriais (paroksetinu, fluoksetinu, venlafaksinu, } \\
\text { duloksetinu, bupropionu, chinidinu, terbinafinu, cinakalcetu), kadangi pitolisanto poveikis padidejja 2 kartus. }\end{array}$ \\
\hline $\begin{array}{l}\text { Siauros terapinės } \\
\text { platumos vaistai, } \\
\text { kiti preparatai }\end{array}$ & $\begin{array}{l}\text { Siauros terapinės platumos vaistai (pvz., imunosupresantai, docetakselis, kinazės inhibitoriai, cisapridas, } \\
\text { pimozidas, halofantrinas) kartu su pitolisantu nevartotini. Vartojant pitolisantą su kitais vaistais (efavirenzu, } \\
\text { bupropionu, repaglinidu, fenitoinu, varfarinu, dabigatranu, digoksinu, morfinu, paracetamoliu, irinotekanu), } \\
\text { reikia imtis atsargumo priemonių - vykdyti klinikinę veiksmingumo stebėseną. Rekomenduojama } \\
\text { pitolisantą kartu su metforminu (biguanidu) vartoti atsargiai. }\end{array}$ \\
\hline $\begin{array}{l}\text { Geriamieji } \\
\text { kontraceptikai }\end{array}$ & $\begin{array}{l}\text { Geriamujų kontraceptikų ir pitolisanto derinys nevartotinas - turi būti naudojamas kitas patikimas } \\
\text { kontraceptinis metodas. }\end{array}$ \\
\hline
\end{tabular}

Santrumpos: AUC (angl. area under the curve) - plotas po kreive. 
terapinės platumos vaistai kartu nevartotini. Ivvertinus pitolisanto derinio su modafiniliu arba natrio oksibatu terapines dozes, neaptikta jokios svarbios farmakokinetinès šiu vaistų sąveikos. Vadinasi, pitolisantą galima vartoti tiek monoterapijai, tiek politerapijai kartu su modafiniliu arba natrio oksibatu.

Pitolisantas yra gerai toleruojamas vaistas, nepageidaujamos reakcijos pasitaiko retai. Dažniausiai registruotos nepageidaujamos reakcijos buvo nemiga $(8,4 \%)$, galvos skausmas $(7,7 \%)$, pykinimas $(4,8 \%)$, nerimas $(2,1 \%)$, dirglumas $(1,8 \%)$, svaigulys $(1,4 \%)$, depresija $(1,3 \%)$, drebulys $(1,2 \%)$, miego sutrikimai $(1,1 \%)$, nuovargis $(1,1 \%)$, vėmimas $(1 \%)$, galvos svaigimas $(1 \%)$, dispepsija (1\%), svorio padidejjimas $(0,9 \%)$, viršutinès pilvo dalies skausmas $(0,9 \%)$ [38].

Pitolisanto nutraukimas nesukelia nutraukimo sindromo simptomatikos. Tyrime, atliktame 2017 m. Kanadoje su asmenimis, rekreaciniais tikslais vartojančiais stimuliantus, nustatyta, kad pitolisantas nesukèlè piktnaudžiavimo rizikos, lyginant su CNS stimuliantu fenterminu (savo struktūra panašiu ị amfetaminą). Pitolisanto piktnaudžiavimo ir pripratimo rizika buvo panaši ì placebo [39]. Tai aiškinama tuo, kad pitolisantas tiesiogiai neveikia dopamino išsiskyrimo nucleus accumbens srityje, vienoje iš svarbiausių CNS struktūrų, atsakingų už motyvaciją, pasišlykštėjimą, malonumą, teigiamo sustiprinimo ir priklausomybės susiformavimo procesą [40]. Dẻl šių priežasčių pitolisantas nėra ịtrauktas ị ES kontroliuojamų medžiagụ sąrašą.

Taigi pitolisantas - ne tik pripratimo nesukeliantis, sąlyginai saugus, patogus vartoti ligoniui, bet ir pasižymintis dvigubu efektu - patologinio mieguistumo slopinimu ir katapleksijos priepuolių retinimu narkolepsija sergančiam ligoniui.

\section{ATEITIES PERSPEKTYVOS}

Solriamfetolis (JZP-110) - fenilalanino darinys, dopamino ir noradrenalino reabsorbcijos inhibitorius, $2019 \mathrm{~m}$. patvirtintas JAV narkolepsijai gydyti. Vertinant nepageidaujamas reakcijas, solriamfetolis yra gana saugus vaistas, nesilpnina geriamųjų hormoninių kontraceptikų veiksmingumo, tačiau yra ịtrauktas ị kontroliuojamų medžiagų sąrašą dèl galimo pripratimo ir piktnaudžiavimo rizikos. Nors solriamfetolis efektyviau mažina patologini mieguistumą nei modafinilis ar armodafinilis, tačiau nepakankamai efektyviai retina katapleksijos priepuolius [41, 42].

Naujosios natrio oksibato versijos - vieną kartą per naktị vartojamas FT218 ir mažai natrio turintis JZP-258 priklauso dar tiriamų vaistų grupei. Natrio oksibatas - gama hidroksibutirato natrio druska, neurotransmiteris ir neuromoduliatorius, veikiantis dopamino, serotono, gama aminosviesto rūgšties ir opioidines sistemas, sukeliantis CNS slopinimą, miego konsolidaciją, retinantis katapleksijos priepuolius. Tikimasi, kad FT218 preparatą bus pato- giau vartoti, o JZP-258 (natrio, kalio, kalcio ir magnio oksibatų mišini), kuriame natrio yra $92 \%$ mažiau nei natrio oksibate, bus saugiau vartoti ir šis vaistas turès mažiau nepageidaujamų reiškinių [41].

AXS-12 (reboksetinas) - selektyvus noradrenalino reabsorbcijos inhibitorius, sukurtas depresijai gydyti. Šiuo metu vyksta klinikiniai tyrimai, siekiant ịrodyti šio preparato efektyvumą narkolepsija sergančių ligonių patologiniam mieguistumui mažinti ir katapleksijos priepuoliams retinti. Galimai šis vaistas bus alternatyva ligoniams, kuriems diagnozuotos narkolepsija ir depresija, taip pat tiems, kurie netoleruoja pitolisanto ar natrio oksibato [43].

THN102 (modafinilio ir flekainido kombinacija) tiriamas dẻl efektyvumo narkolepsija sergančių ligonių patologiniam mieguistumui mažinti. Modafinilis veikia ne tik didindamas užląstelinio dopamino koncentraciją hipokretino receptoriuose, bet ir moduliuodamas koneksinus. Astroglijos ir astrocitų koneksinai galimai veikia miego-budrumo ciklą. Flekainidas - astroglijos koneksinų inhibitorius, pagerinęs modafinilio budrumą didinantị poveikį tyrimuose su gyvūnais [41].

TAK-925, TAK-994 - selektyvūs hipokretino / oreksino-2 receptorių agonistai tyrimuose su gyvūnais sumažino patologinị mieguistumą, suretino katapleksijos epizodus [44]. Taip pat pastaraisiais metais tiriamas oreksino peptidų, neuronų transplantacijos, kamieninių ląstelių ir genų terapijos poveikis narkolepsijos simptomų kontrolei ir gydymui [41].

\section{IŠVADOS}

1. Inkubo fenomenas, šiandien suprantamas kaip miego paralyžius su hipnogoginėmis ar hipnopompinėmis haliucinacijomis, buvo minimas jau senujų civilizacijų epuose, Senajame Testamente ir Talmude. Viduramžiais ir Renesanso laikotarpiu asmenys, veikiausiai sirgę narkolepsija arba REM parasomnija, buvo „gydomi“, atliekant egzorcizmo seansus.

2. XIX a. pradžioje Vilniuje inkubo liga buvo gydoma, ligoniui pateikiant gyvenimo būdo, dietos, miego higienos rekomendacijas, didelę reikšmę turèjo antiflogistinis gydymas: kraujo nuleidimai, klizmos, vėmimą sukeliantys vaistai; ligoniams taip pat išrašyti vaistai nuo kirmèlių, priešspazminiai, tonizuojantys vaistai ir chininmedžio žievė.

3. Tik XX a. pabaigoje nustačius, kad narkolepsija - tai centrinės kilmės hipersomnija, pasireiškianti dėl dalinio arba visiško hipokretiną sekretuojančių neuronų netekimo pogumburyje, atsirado efektyvaus simptominio gydymo galimybių. Pirmojo pasirinkimo vaistai, iki šiol naudoti padidejusiam mieguistumui mažinti, buvo modafinilis, armodafinilis, pitolisantas ir natrio oksibatas. Antrojo pasirinkimo - metilfenidatas. Trečiojo - amfetamino grupès psichostimuliantai. Pirmojo pasirinkimo vaistai, iki šiol naudoti katapleksijos 
priepuoliams retinti, buvo natrio oksibatas, pitolisantas ir venlafaksinas. Antidepresantų vartojimas, slopinant katapleksijos priepuolius, buvo pagrịstas ekspertų susitarimu: pirmiausia rekomenduota išbandyti SSRI ar SNRI grupès antidepresantus, nesant efekto - skirti triciklius antidepresantus. Šių metų rudenị Berlyne vykusioje 17-ojoje Europos narkolepsijos konferencijoje pristatytos dar nepublikuotos, tačiau Europos neurologijos akademijos, Europos miego tyrimų draugijos ir Europos narkolepsijos tinklo patvirtintos naujos narkolepsijos gydymo gairès nežymiai pakoregavo narkolepsijos gydymo principus.

4. Pitolisantas - unikalus histamino $\mathrm{H} 3$ receptorių antagonistas / atvirkštinis agonistas, vienintelis iš rinkoje esančių ir narkolepsijai gydyti skirtų pripratimo nesukeliančių CNS stimuliantų, skirtas suaugusių ligonių, sergančių narkolepsija, patologiniam mieguistumui mažinti ir katapleksijos priepuoliams retinti. Pitolisantas šiandien yra vienintelis kompensuojamasis vaistas Lietuvoje, skirtas narkolepsijai gydyti.

5. Ateityje vaistų, skirtų narkolepsijos simptomų kontrolei, sąrašą veikiausiai papildys naujosios natrio oksibato versijos, selektyvus noradrenalino reabsorbcijos inhibitorius reboksetinas, modafinilio ir astroglijos koneksinų inhibitoriaus flekainido kombinacija ar selektyvūs hipokretino-2 receptorių agonistai.

\section{Literatūra}

1. Molendijk ML, Montagne $\mathrm{H}$, Bouachmir O, Alper Z, Bervoets JP, Blom JD. Prevalence rates of the incubus phenomenon: a systematic review and meta-analysis. Front Psychiatry 2017; 8: 253. https://doi.org/10.3389/fpsyt. 2017.00253

2. Cox AM. Sleep paralysis and folklore. J R Soc Med Open 2015; 6(7): 1-4. https://doi.org/10.1177/ 2054270415598091

3. Stephens W. Demon lovers. Witchcraft, sex and the crisis of belief. London and Chicago: The University of Chicago Press, 2002.

4. Davies O. The nightmare experience, sleep paralysis, and witchcraft accusations. Folklore 2003; 114: 181-203. https://doi.org/10.1080/0015587032000104211

5. Mather C. Cotton Mather on witchcraft. New York: Dorset Press, 1991.

6. Kompanje EJO. 'The devil lay upon her and held her down'. Hypnagogic hallucinations and sleep paralysis described by the Dutch physician Isbrand van Diemerbroeck (1609-1674) in 1664. J Sleep Res 2008; 17: 464-67. https://doi.org/ 10.1111/j.1365-2869.2008.00672.x

7. Willis T. De Anima Brutorum, quae Hominis Vitalis ac Sensitiva est, Exercitationes duae. London: Impensis Ric. Davis, 1672.

8. Frank J. Praxeos medicae universae praecepta. Partis secundae volumen primum, sectio prima, continens doctrinam de morbis systematis nervosi in genere et de iis cerebri in specie. Lipsiae: sumptibus Bibliopolii Kuehniani, 1818.

9. Caffé J. Maladie du sommeil. J des Connaissances Médicales et Pharmaceutiques 1862; 29: 323.
10. Westphal C. Eigenthümliche mit Einschläfen verbundene Anfälle. Arch Psychiatr 1877; 7: 631-5.

11. Pelayo R, Hodgson N, Guilleminault C. The history of sleep medicine. Handb Clin Neurol 2010; 95: 547-56. https://doi.org/10.1016/S0072-9752(08)02134-9

12. Daniels L. Narcolepsy. Medicine 1934; 13: 1-122. https://doi.org/10.1097/00005792-193413010-00001

13. Doyle J, Daniels L. Symptomatic treatment for narcolepsy. JAMA 1931; 96: 1370-2. https://doi.org/10.1001/jama. 1931.02720430020006

14. Prinzmetal M, Bloomberg W. The use of benzedrine for the treatment of narcolepsy. JAMA 1935; 105: 2051-4. https://doi.org/10.1001/jama.1935.02760510023006

15. Voegel G. Studies in psychophysiology of dreams. III. The dream of narcolepsy. Arch Gen Psychiatry 1960; 3: 421-8. https://doi.org/10.1001/archpsyc.1960.01710040091011

16. Schwartz JC. The histamine $\mathrm{H} 3$ receptor: from discovery to clinical trials with pitolisant. Br J Pharmacol 2011; 163: 713-21. https://doi.org/10.1111/j.1476-5381. 2011.01286.x

17. Guilleminault C, Grumet C. HLA-DR2 and narcolepsy: not all narcoleptic-cataplectic patients are DR2. Hum Immunol 1986; 17:1-2. https://doi.org/10.1016/01988859(86)90068-6

18. Peyron C, Faraco J, Rogers W, Ripley B, Overeem S, Charnay Y, et al. A mutation in a case of early onset narcolepsy and a generalized absence of hypocretin peptides in human narcoleptic brains. Nat Med 2000; 6: 991-7. https://doi.org/10.1038/79690

19. von Economo C. Sleep as a problem of localization. J Nerv Ment Dis 1930; 71: 249-59. https://doi.org/10.1097/ 00005053-193003000-00001

20. Mignot E. Narcolepsy: genetics, immunology, and pathophysiology. In: Kryger M, Roth T, Dement WC, eds. Principles and practice of sleep medicine. Sixth edition. Philadelphia: Elsevier, 2017; 855-72.

21. Oberle D, Pavel J, Mayer G, Geisler P, KellerStanislawski B, for the German Narcolepsy Study Group. Retrospective multicenter matched case-control study on the risk factors for narcolepsy with special focus on vaccinations (including pandemic influenza vaccination) and infections in Germany. Sleep Medicine 2017; 34: 71-83. https://doi.org/ 10.1016/j.sleep.2017.02.026

22. Baltakytė E, Popa A, Pajëdienė E. Narkolepsija: atvejo pristatymas ir literatūros apžvalga. Neurologijos seminarai 2019; 23(82): 214-20. https://doi.org/10.29014/ns.2019.28

23. Cao MT, Guilleminault C. Narcolepsy: diagnosis and management. In: Kryger M, Roth T, Dement WC, eds. Principles and practice of sleep medicine. Sixth edition. Philadelphia: Elsevier, 2017: 873-82.

24. Matačiūnienė D, Mameniškienė R, Jatužis D, Budrys V. Narkolepsijos diagnostikos klystkeliai: klinikinis atvejis ir literatūros apžvalga. Neurologijos seminarai 2012; 16(51): 61-5.

25. Barateau L, Dauvilliers Y. Recent advances in treatment for narcolepsy. Ther Adv Neurol Disord 2019; 12: 1-12. https://doi.org/10.1177/1756286419875622

26. Kallweit U, Bassetti CL. Pharmacological management of narcolepsy with and without cataplexy. Expert Opin on Pharmacother 2017; 18(8): 809-17. https://doi.org/10.1080/ 14656566.2017.1323877

27. Valstybinè vaistų kontrolès tarnyba. Vaistų registracija. Metilfenidato hidrochloridas. Prieiga internete: https://vapris.vvkt.lt/vvkt-web/public/medications?show Data $=$ true $\&$ mainSearchField $=$ metilfeni $\&$ full Name $=\&$ 
substance $=\&$ strength $=\&$ pharmaceuticalForm $=\&$ medication State $=3 \&$ medication State $=2 \&$ atc Code $=\& \mathrm{rtt}=\& \mathrm{rttNumber}=$ \&procedureNumber [Žiūrèta 2020-05-20].

28. Valstybinè vaistų kontrolès tarnyba. Vaistų registracija Venlafaksinas. Prieiga internete: https://vapris.vvkt.lt/ vvkt-web/public/medications?showData=true\&mainSearch Field $=$ Venlafaksinas $\&$ fullName $=\&$ substance $=\&$ strength $=$ $\&$ pharmaceuticalForm $=\&$ medicationState $=3 \&$ medication State $=2 \&$ atcCode $=\& \mathrm{rtt}=\& \mathrm{rttNumber}=\&$ procedureNumber [Žiūrèta 2020-05-20].

29. Valstybinė vaistų kontrolès tarnyba. Vaistų registracija. Duloksetinas. Prieiga internete: https://vapris.vvkt.lt/vvkt-web/ public/medications? showData $=$ true $\&$ mainSearchField $=$ Duloksetinas $\&$ full Name $=\&$ substance $=\&$ strength $=\&$ pharmaceuticalForm $=\&$ medication $S$ tate $=3 \&$ medication State $=2 \&$ atc $\operatorname{Code}=\& \mathrm{rtt}=\& \mathrm{rttNumber}=\boldsymbol{\&}$ procedureNumber [Žiūrèta 2020-05-20].

30. Valstybinė vaistu kontrolès tarnyba. Vaistu registracija. Fluoksetinas. Prieiga internete: https://vapris.vvkt.lt/ vvkt-web/public/medications?showData=true\&mainSearch Field $=$ Fluoksetinas $\&$ fullName $=\&$ substance $=\&$ strength $=\&$ pharmaceuticalForm $=\&$ medicationState $=3 \&$ medication State $=2 \&$ atc Code $=\& \mathrm{rtt}=\& \mathrm{rttNumber}=\&$ procedureNumber [Žiūrèta 2020-05-20].

31. Valstybinė vaistų kontrolès tarnyba. Vaistų registracija. Klomipraminas. Prieiga internete: https://vapris.vvkt.lt/ vvkt-web/public/medications?showData=true\&mainSearch Field $=$ klomipram $\&$ full Name $=\&$ substance $=\&$ strength $=\&$ pharmaceuticalForm $=\&$ medicationState $=3 \&$ medication State $=2 \&$ atc $\operatorname{Code}=\& \mathrm{rtt}=\& \mathrm{rttNumber}=\&$ procedureNumber [Žiūrèta 2020-05-20].

32. Lamb YN. Pitolisant: a review in narcolepsy with or without cataplexy. CNS Drugs 2020; 34: 207-18. https://doi.org/ 10.1007/s40263-020-00703-x

33. Valstybinė vaistų kontrolès tarnyba. Vaistų registracija. Pitolizantas. Prieiga internete: https://vapris.vvkt.lt/vvkt-web/ public/medications? showData $=$ true $\&$ mainSearchField $=$ pitol\&fullName $=\&$ substance $=\&$ strength $=\&$ pharmaceutical Form $=\&$ medicationState $=3 \&$ medicationState $=2 \&$ atc Code $=\& \mathrm{rtt}=\& \mathrm{rttNumber}=\&$ procedureNumber $[$ Žiūrèta 2020-05-20].

34. Lietuvos Respublikos Sveikatos apsaugos ministerijos Vaistiniu preparatu ir medicinos pagalbos priemonių kompensavimo komisija. Dėl vaistinio prepataro pitolisanto (Wakix) kompensavimo. $2020 \mathrm{~m}$. balandžio 3 d. protokolas. Prieiga internete: http://sam.lrv.lt/uploads/sam/documents/files/ 2020-04-03\% 20vie\% C5\%A1as\%20protokolas.pdf [Žiūrèta 2020-06-18].

35. Dauvilliers Y, Bassetti C, Lammers GJ, Arnulf I, Mayer G, Rodenbeck A, et al. Pitolisant versus placebo or modafinil in patients with narcolepsy: a double-blind, randomised trial. Lancet Neurol 2013; 12: 1068-75. https://doi.org/10.1016/ S1474-4422(13)70225-4

36. Szakacs Z, Dauvilliers Y, Mikhaylov V, Poverennova I, Krylov S, Jankovic S, et al. Safety and efficacy of pitolisant on cataplexy in patients with narcolepsy: a randomised, double-blind, placebo-controlled trial. Lancet Neurol 2017; 16: 200-7. https://doi.org/10.1016/S1474-4422(16)30333-7

37. Dauvilliers Y, Arnulf I, Szakacs Z, Leu-Semenescu S, Lecomte I, Scart-Gres C, et al. Long-term use of pitolisant to treat patients with narcolepsy: Harmony III Study. Sleep J 2019; 42(11): 1-11. https://doi.org/10.1093/sleep/zsz174

38. Preparato charakteristikų santrauka. Pitolizantas. Prieiga internete: https://ec.europa.eu/health/documents/community- register/2017/20171013139128/anx_139128_lt.pdf [Žiūrèta 2020-05-20].

39. Setnik B, McDonnell M, Mills C, Scart-Grès C, Robert P, Dayno JM, et al. Evaluation of the abuse potential of pitolisant, a selective $\mathrm{H} 3$-receptor antagonist/inverse agonist, for the treatment of adult patients with narcolepsy with or without cataplexy. Sleep 2020; 43(4): zsz252. https://doi.org/10.1093/sleep/zsz252

40. Uguen M, Perrin D, Belliard S, Ligneau X, Beardsley PM, Lecomte JM, et al. Preclinical evaluation of the abuse potential of Pitolisant, a histamine $\mathrm{H} 3$ receptor inverse agonist/antagonist compared with Modafinil. Br J Pharmacol 2013; 169(3): 632-44. https://doi.org/10.1111/bph.12149

41. Thorpy MJ. Recently approved and upcoming treatments for narcolepsy. CNS Drugs 2020; 34: 9-27. https://doi.org/ 10.1007/s40263-019-00689-1

42. Ruoff C, Swick TJ, Doekel R, Emsellem HA, Feldman NT, Rosenberg R, et al. Effect of oral JZP-110 (ADX-N05) on wakefulness and sleepiness in adults with narcolepsy: a phase 2b study. Sleep 2016; 39(7): 1379-87. https://doi.org/10.5665/sleep.5968

43. Larrosa O, de la Llave Y, Bario S, Granizo JJ, GarciaBorreguero D. Stimulant and anticataplectic effects of reboxetine in patients with narcolepsy: a pilot study. Sleep 2001; 24(3): 282-5. https://doi.org/10.1093/sleep/24.3.282

44. Evans R, Tanaka S, Tanaka S, Touno S, Shimizu K, Sakui S, et al. A phase 1 single ascending dose study of a novel orexin 2 receptor agonist, TAK-925, in healthy volunteers (HV) and subjects with narcolepsy type 1 (NT1) to assess safety, tolerability, pharmacokinetics, and pharmacodynamic outcomes [oral presentation]. World Sleep Congress; 20-25 Sep 2019; Vancouver. https://doi.org/10.1016/j.sleep. 2019.11.290

45. Bassetti C, Kallweit U. New European Management Guidelines [oral presentation]. 17th European Narcolepsy Masterclass; 5 Sep 2020; Berlin.

46. Lin JS. Brain structures and mechanisms involved in the control of cortical activation and wakefulness, with emphasis on the posterior hypothalamus and histaminergic neurons. Sleep Med Rev 2000; 4(5): 471-503. https://doi.org/10.1053/ smrv.2000.0116

\section{E. Sakalauskaitè-Juodeikienè, R. Masaitienè}

\section{NARCOLEPSY TREATMENT: FROM EXORCISM AND BLOODLETTING TO MODERN THERAPY WITH HISTAMINE RECEPTOR INVERSE AGONISTS}

\section{Summary}

In this review article, we present the treatment of narcolepsy since ancient times when patients experiencing the phenomenon of incubus (today understood as sleep paralysis with hypnagogic or hypnopompic hallucinations) were "cured" during the sessions of exorcism. At the beginning of the 19th century, in Vilnius clinics, the incubus disease was treated by providing lifestyle, diet, and sleep hygiene recommendations, also using antiphlogistic methods, as well as antispasmodic medicine and quinine bark. It was not until the late 20th century, when narcolepsy was perceived as a central hypersomnia due to partial or complete loss of hypocretin-secreting neurons in the hypothalamus, that effective symptomatic treatment emerged. Psychostimulants such as modafinil, armodafinil, pitolisant, and sodium oxybate were the first-line strategies. In second line, methylphenidate could be used. Amphetamine mixed salts or D-amphet- 
amine could only be used in the third line because of potential cardiovascular and psychiatric side effects. Sodium oxybate, pitolisant, and venlafaxine were the first-line medications recommended for cataplexy. Serotonin and noradrenaline reuptake inhibitors were also often prescribed to manage cataplexy, while low doses of tricyclic antidepressants were used as third-line treatment. In this paper, we also present new European management guidelines for narcolepsy presented in 17th European Narcolepsy Masterclass in Berlin in September 5, 2020. Pitolisant, one of the latest drugs used for the symptomatic treatment of type I and II narcolepsy in adults, is a unique histamine $\mathrm{H} 3$ receptor antagonist/reverse agonist, the only wake-promoting agent in the market without risk of abuse. Currently, the treatment of narcolepsy with pitolisant is reimbursed in Lithuania. In this article, we also review future perspectives for narcolepsy treatment including novel versions of sodium oxybate, the noradrenaline reuptake inhibitor reboxetine, the combination of modafinil and the astroglial connexins inhibitor flecainide, selective hypocretin-2 receptor agonists, and immune-based therapies.

Keywords: narcolepsy, incubus, hypocretin, treatment, histamine receptor inverse agonists, pitolisant.

Priimta spaudai: 20200801 